\title{
Technologia klejenia i właściwości złącza klejowego kompozytowych pian aluminiowych
}

\author{
Gluing technology and properties \\ of composite aluminum foams glued joint
}

\section{Streszczenie}

W artykule przedstawiono przykład rozwiązania konstrukcji złącza klejowego piany aluminiowej wykonanego przy użyciu dwuskładnikowego kleju epoksydowego. Sformułowano założenia dla złącza dotyczące rozkładu sił i naprężeń w rozciąganej próbce. Ustalono zalecenia do przygotowania powierzchni pian, procedurę klejenia uwzględniającą kontrolę porowatości piany i chropowatości klejonej powierzchni blachy. W wyniku badań wytrzymałościowych określono mechanizm niszczenia złącza. Zaproponowano optymalizację konstrukcji złącza poprawiającą jego właściwości.

Słowa kluczowe: złącze klejowe, piana aluminiowa, klejenie, badania wytrzymałościowe

\section{Abstract}

The paper presents an example of design solution of aluminum foam glue joint using two-component epoxy glue. The joint principles for distribution forces and stresses in the tensile sample were formulated. Recommendations for surface preparation of foam and gluing procedure aimed at control the porosity of the foam and glued surface roughness were established. As a result of strength tests defined joint destruction mechanism was proposed. It was suggested that optimized joint design improving its properties.

Keywords: glue joint, aluminum foam, gluying, mechanical tests

\section{Wstęp}

Piany aluminiowe są specyficznymi tworzywami konstrukcyjnymi o porowatości często przekraczającej $90 \%$. Cechami charakteryzującymi materiał są: niska gęstość, wysoka sztywność, zdolność pochłaniania energii, tłumienie fal akustycznych i drgań mechanicznych.

Właściwości pian aluminiowych determinują ich liczne zastosowanie $w$ takich dziedzinach jak motoryzacja, lotnictwo i aeronautyka. Piany stosuje się także w budowie maszyn i urządzeń, a także w budownictwie lądowym. W budowie okrętów używa się ich przykładowo na komponenty drzwi, włazów, wręg, wzmocnień części ładunkowych i elementów poszycia.

Efektywne wykorzystanie pian aluminiowych w różnorodnych konstrukcjach i urządzeniach wymaga skutecznych metod trwałego łączenia uwzględniających charakter ich pracy i stan obciążenia.

Struktura komórkowa i wyjątkowe cechy metalicznych pian aluminiowych generują liczne problemy związane z ich cięciem i spajaniem. Aktualnie piany metaliczne wytwarzane są ze wszystkich dostępnych metali, w szczególności z aluminium, magnezu, tytanu, cynku, niklu, miedzi i żelaza lub ich stopów [1].

Aluminiowe piany metaliczne dzięki swoim cechom znajdują szerokie zastosowanie jako elementy tłumiące drgania, hałas i wibracje w budowie obrabiarek oraz elementy pochłaniające energię uderzenia w przemyśle środków transportu. Szeroko stosuje się je także

Dr inż. Adam Sajek - Zachodniopomorski Uniwersytet Technologiczny w Szczecinie.

Autor korespondencyjny/corresponding author: adam.sajek@zut.edu.pl 
w przemyśle elektrotechnicznym i aparatury chemicznej. Możliwe jest zastosowanie pian w konstrukcji ognioodpornych grodzi w statkach. Pole zastosowań pian metalicznych ciągle się poszerza, co dowodzi, że jest to atrakcyjny i innowacyjny materiał konstrukcyjny.

Do typowych złączy wykorzystywanych w produkcji pian należą połączenia śrubowe, lutowane, klejone, spawane [2].

\section{Klejenie pian aluminiowych}

W wielu przypadkach zachodzi konieczność łączenia elementów pian aluminiowych metodą klejenia, którego zaletą jest niska temperatura operacji - niepowodująca naruszenia ich krystalicznej struktury. Jednak ze względu na dużą porowatość pian aluminiowych ich klejenie stwarza wiele trudności technologicznych [2].

Można znaleźć nieliczne publikacje omawiające technologię klejenia pian aluminiowych.

N. Sedliaková i inni sugerują możliwość wytworzenia złączy klejowych na pianach aluminiowych o wytrzymałości przekraczającej wytrzymałość piany za pomocą wszystkich rodzajów klejów zalecanych do klejenia aluminium nieporowatego [3].

S. Bartolucci zaleca stosowanie do klejenia pian aluminiowych klejów epoksydowych utwardzanych w temperaturze $180^{\circ} \mathrm{C}$ w czasie $30 \mathrm{~min}$ [4].

H.P. Degischer, powołując się na poprzednie publikacje stwierdził, że klejenie jest metodą użyteczną w łączeniu pian aluminiowych, a użycie klejów termorozszerzalnych pozwoliłoby zmostkować ewentualne pustki wynikające z niedokładnego spasowania elementów klejonych. Wskazywał też na kleje termoutwardzalne jako potencjalnie atrakcyjne do łączenia pian w przemyśle motoryzacyjnym, ponieważ wiązanie kleju następowałoby bez dodatkowych zabiegów, podczas procesu lakierowania w podwyższonych temperaturach [5].

O.B. Olurin i inni badali wytrzymałość na rozciąganie i zginanie złączy mechanicznych z użyciem śrub, gwoździ i kołków, oraz złączy klejowych doczołowych i zakładkowych na pianach $\mathrm{Al}$ o gęstości względnej $0,08 \div 0,15$ klejonych żywicą epoksydową, która po nałożeniu kleju była pozostawiona do związania na $24 \mathrm{~h}$. Autorzy stwierdzili, że złącze klejowe ma wytrzymałość większą niż piana i jest optymalne, o ile jego mała odporność termiczna nie jest istotna ze względów eksploatacyjnych [6].

J. Burzer i inni porównują wytrzymałość na ścinanie połączeń klejowych z użyciem dwuskładnikowego kleju termoutwardzalnego oraz spawanych. Znacznie większą wytrzymałość na ścinanie próbek spawanych autorzy tłumaczą wnikaniem stopionego spoiwa metalicznego w pory piany [7].

T. Bernard i inni określają jako standardowe w przemyśle motoryzacyjnym klejenie struktur laminarnych za pomocą klejów termoutwardzalnych początkowo w temperaturze $50^{\circ} \mathrm{C}$, a następnie przez $30 \mathrm{~min}$ w temperaturze $190^{\circ} \mathrm{C}[8]$.
Krajewski S. i Nowacki J. w [9] opracowali metodę przygotowania krawędzi pian aluminiowych do spajania.

Nowacki J., Grabian J. i Krajewski S. w [10] badali możliwości spajania pian aluminiowych metodą lutowania osiągając wysokie wytrzymałości złącza, większe od wytrzymałości materiału rodzimego.

Większość przeanalizowanych publikacji, w których omówiono klejenie pian aluminiowych, skupia się na innych problemach, pozostawiając technologię klejenia opisaną bardzo pobieżnie.

Na przykład R. Panowicz i inni skupiają się na symulacji numerycznej dynamicznego oddziaływania fali ciśnienia na złożoną strukturę panelu energochłonnego oraz walidacji wyników. Nie opisano właściwości piany aluminiowej oraz technologii klejenia. Wspomniany klej jest pianką poliuretanową, która nie została dokładnie przebadana pod względem wytrzymałości [11].

W kolejnej pracy, dotyczącej badań eksperymentalnych i modelowania piany aluminiowej ALPORAS, M. Klasztorny i inni, walidując model obliczeniowy do badań wytrzymałościowych użyli próbek klejonych zakładając, że złącze klejone nie stanowi istotnego elementu eksperymentu [12].

Klejenie pian aluminiowych jest często bagatelizowane i traktowane jako uzupełnienie procesu łączenia badanych próbek. Brak jest dyskusji o właściwościach zastosowanych klejów, procedurze klejenia czy przygotowaniu klejonych powierzchni. Poniższa praca stanowi próbę wypełnienia istniejącej luki.

\section{Założenia konstrukcyjne złącza}

Dla próbki wytrzymałościowej głównym założeniem konstrukcyjnym jest odpowiednia orientacja naprężeń. W projektowanym złączu powinny dominować adekwatne do połączenia klejowego naprężenia ścinające, które koncentrują się w klejowej spoinie, powodując jej zniszczenie.

Aby wykonać prawidłową próbkę do badań wytrzymałościowych, należy spełnić warunek, w którym wytrzymałość na ścinanie badanego połączenia klejowego powinna być mniejsza niż wytrzymałość klejonych materiałów.

Zaprojektowane złącze zostało wykonane na zakładkę pomiędzy aluminiową blachą spełniającą rolę części chwytowej próbki, a pianą aluminiową. Blachy ze stopu aluminium AISi9Mg (AK9) wykorzystano jako części chwytowe, a użyta w złączu kompozytowa piana aluminiowa wykonana została metodą wdmuchiwania gazu do roztopionego stopu siluminu AISi9. Budowę próbki testowej przedstawiono na rysunku 1.

Materiały sklejono za pomocą dwuskładnikowego kleju epoksydowego (Loctite Hysol 9489).

Podstawą wyznaczenia siły zrywającej danego elementu złącza była dla kleju wytrzymałość na ścinanie oraz wytrzymałość na rozciąganie dla pozostałych materiałów. 
Wyniki obliczeń przedstawiono $\mathrm{w}$ tablicy I. Z obliczeń wynika, że najniższą wartość siły zrywającej 7,4 kN mieć będzie spoina klejowa. Drugim co do wytrzymałości elementem układu jest blacha aluminiowa, dla której wartość siły zrywającej jest o ponad 3 kN



Rys. 1. Próbka wytrzymałościowa do próby ścinania

Fig. 1. The shear test sample

a)



c)

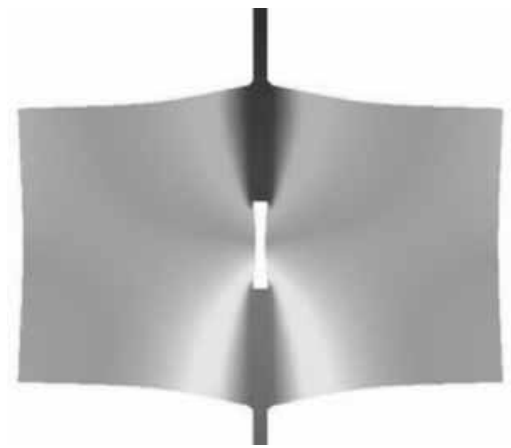

URES (mm)



wyższa. Stanowi to bezpieczny, ponad $40 \%$ zapas. Dla piany aluminiowej, jako elementu najbardziej nieprzewidywalnego, wartość siły zrywającej jest ponad dwukrotnie wyższa od siły zrywającej kleju.

Wykonano wstępne symulacje rozkładu naprężeń i odkształceń metodą elementów skończonych. Do tego celu użyto modułu oprogramowania SolidWorks Simulation pakietu SolidWorks 2013. Badaniu poddano model dyskretny 2D oparty na przekroju poprzecznym próbki wytrzymałościowej, przedstawiony na rysunku 2a. W analizie MES dla użytych materiałów zastosowano dane materiałowe przedstawione w tablicy II.

Wyniki symulacji numerycznej rozciąganego złącza przedstawione na rysunku 2 wskazują zarówno na

b)

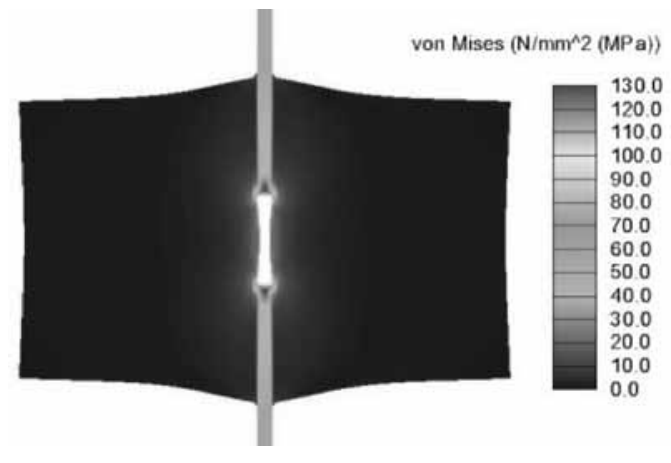

d)

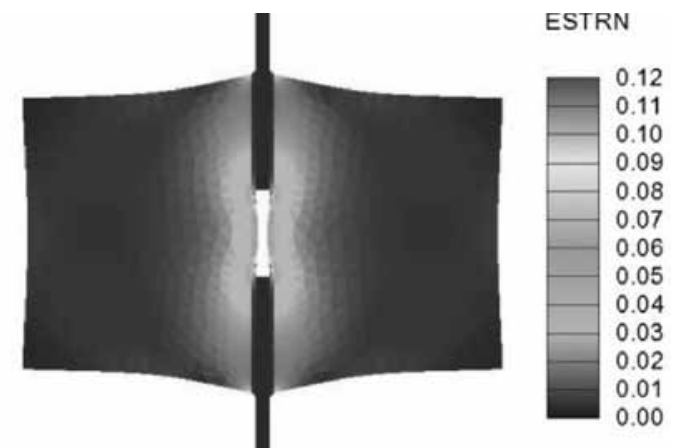

Rys. 2. Wyniki analizy numerycznej projektowanego złącza: a) model z podziałem na elementy, b) rozkład naprężeń w złączu, c) rozkład przemieszczeń, d) rozkład odkształceń

Fig. 2. Results of numerical analysis designed joint: a) model divided into elements, b) stress distribution, c) distribution of displacements, d) strain distribution

Tablica I. Obliczone wartości sił zrywających dla próbki do badań wytrzymałości na ścinanie

Table I. Calculated values destructive forces for the shear strength test sample

\begin{tabular}{|c|c|c|c|c|c|c|}
\hline \multirow{2}{*}{ Materiał } & \multicolumn{2}{|c|}{ Wymiary } & \multirow{2}{*}{$\begin{array}{l}\text { Liczba } \\
\text { próbek }\end{array}$} & \multirow{2}{*}{$\begin{array}{c}\text { Powierzchnia } \\
\text { nośna } \\
\mathrm{S}_{0}, \mathrm{~mm}^{2} \\
\end{array}$} & \multirow{2}{*}{$\begin{array}{c}\text { Wytrzymałość na } \\
\text { rozciąganie } \\
R_{m}\left(R_{s}\right), M P a \\
\end{array}$} & \multirow{2}{*}{$\begin{array}{l}\text { Wartość siły } \\
\text { zrywającej } \\
F_{m}\left(F_{s}\right), k N\end{array}$} \\
\hline & $\mathrm{a}, \mathrm{mm}$ & $\mathrm{b}, \mathrm{mm}$ & & & & \\
\hline Blacha klejona & 1,5 & 25,0 & 1 & 37,5 & 283,0 & 10,6 \\
\hline Piana aluminiowa & 20,0 & 25,0 & 2 & 1000,0 & 15,0 & 15,0 \\
\hline Warstwa kleju & 12,5 & 25,0 & 2 & 625,0 & 11,8 & 7,4 \\
\hline
\end{tabular}

Objaśnienie symboli: a - grubość, mm; b-szerokość, $\mathrm{mm} ; \mathrm{S}_{0}$ - pole powierzchni, $\mathrm{mm}^{2} ; \mathrm{R}_{\mathrm{m}}$ - wytrzymałość na rozciąganie, $\mathrm{MPa} ; \mathrm{R}_{\mathrm{s}}$ - wytrzymałość na ścinanie, $\mathrm{MPa} ; \mathrm{F}_{\mathrm{m}}$ - wartość siły zrywającej, kN; $F_{s}$ - wartość siły ścinającej, $k N$

Tablica II. Dane materiałowe użyte w analizie MES dla elementów złącza klejowego

Table II. Material data used in the FEM analysis for the joint elements

\begin{tabular}{|l|c|c|c|c|c|}
\hline \multicolumn{1}{|c|}{ Nazwa } & $\mathrm{R}_{\mathrm{e}}, \mathrm{N} / \mathrm{mm}^{2}$ & $\mathrm{R}_{\mathrm{m}}, \mathrm{N} / \mathrm{mm}^{2}$ & $\mathrm{E}, \mathrm{N} / \mathrm{mm}^{2}$ & $\mathrm{v}$ & $\rho, \mathrm{g} / \mathrm{cm}^{3}$ \\
\hline Piana AISi9 & 1,4 & 1,62 & 200 & 0,33 & 240 \\
\hline Klej epoksydowy & - & 28 & 2415 & 0,35 & 1100 \\
\hline Blacha AK9 & 551485 & 124084 & 69000 & 0,33 & 2700 \\
\hline
\end{tabular}


koncentrację naprężeń, jak i przemieszczeń w spoinie klejowej. W rzeczywistej próbie ścinania w warunkach statycznego rozciągania zostaną wypełnione początkowe założenia odnośnie kierunku i rodzaju sił występujących w złączu.

\section{Procedura wykonania testowych złączy klejowych}

Ustalenie jednolitych warunków przygotowania próbek wytrzymałościowych jest kluczowym elementem, pozwalającym podczas badań uzyskać miarodajne i łatwe do porównania wyniki. Procedura wykonywania testowych złączy klejowych składała się z etapów polegających na cięciu pian i oceny procesu cięcia, określeniu porowatości pian i chropowatości powierzchni blach.

Próbki cięto za pomocą półautomatycznej przecinarki PRESI Metacome T300 umożliwiającej kontrolę podstawowych parametrów, tj. prędkości obrotowej wynoszącej $3000 \mathrm{obr} / \mathrm{min}$ oraz posuwu równego 50 $\mathrm{mm} / \mathrm{min}$. Cięto bez użycia środka chłodzącego z uwagi na kłopoty z późniejszym usunięciem cieczy z porów piany metalicznej.

Przy założonej niskiej prędkości posuwu nie zaobserwowano nadmiernego nagrzewania się ciętych elementów. Zastosowano dwa typy tarcz tnących: standardową tarczę tnącą przeznaczoną do stali konstrukcyjnych: PFERD SG-ELASTIC, oraz drugą tarczę do cięcia aluminium PRESI MNF.

Po wycięciu i oznaczeniu próbek piany wykonano ocenę makroskopową ciętych powierzchni. Zauważono duże różnice w jakości cięcia w zależności od użytych tarczy, które przedstawiono na rysunku 3.

Powierzchnia cięta tarczą PFERD przeznaczoną do stali konstrukcyjnych miała liczne zniekształcenia spowodowane odkształcaniem plastycznym powstałym w czasie cięcia. Zniekształcenia te układają się w charakterystyczne linie o kołowym kształcie odwzorują-

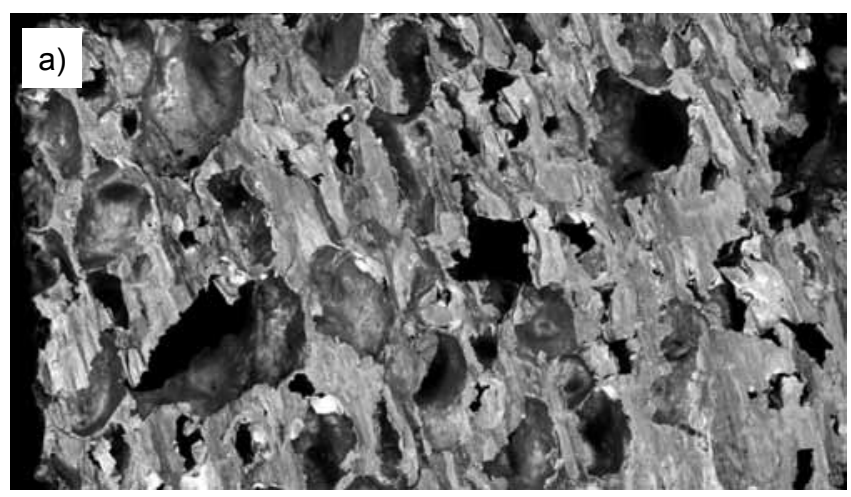

cym ruch tarczy tnącej. Na rysunku 3 widać także pory pozakrywane przez nieodcięte fragmenty struktury piany. Fragmenty te, zamiast ulec oderwaniu, zostały w trakcie cięcia zagięte do środka. Powierzchnia próbek wyciętych zaprojektowaną do stopów aluminium tarczą PRESI MNF jest wolna od zniekształceń, a wszystkie pory są odsłonięte.

Badania mikroskopowe potwierdziły wcześniejsze spostrzeżenia makroskopowe, uwypuklając różnice pomiędzy próbkami ciętymi poszczególnymi typami tarcz.

Po wycięciu próbek kompozytowych pian aluminiowych dokonano pomiaru porowatości. Zastosowano metodę pomiaru porowatości przez ważenie. Pomiary geometrii wykonano w trzech punktach w każdym kierunku (dwa skrajne punkty i jeden pomiar na środku), a następnie je uśredniono. Próbki zważono na wadze laboratoryjnej AXIS AD500 z dokładnością do 0,001 g.

Porowatość poszczególnych próbek obliczono, posługując się poniższą zależnością:

$$
p=\left(1-\frac{m}{V \cdot \rho_{A l}}\right) \cdot 100 \%
$$

gdzie: $p$ - porowatość piany aluminiowej, \%; $V$ - objętość próbki piany aluminiowej, $\mathrm{cm}^{3} ; \mathrm{m}$ - masa próbki piany aluminiowej, g; $\rho_{\mathrm{Al}}-\mathrm{gę-}$ stość siluminu AISi9 wynosząca $2,65 \mathrm{~g} / \mathrm{cm}^{3}$.

Dokonano pomiaru czterech próbek pian aluminiowych, które przedstawiono w tablicy III. Zaobserwowano wysoką powtarzalność oznaczonej porowatości. Średnia wartość porowatości wyniosła 91,1\% przy odchyleniu standardowym wynoszącym 0,465.

Tablica III. Wyniki pomiarów porowatości pian aluminiowych Table III. The results of measurements of porosity aluminum foams

\begin{tabular}{|c|c|c|c|}
\hline Nr próbki & $\mathrm{V}, \mathrm{cm}^{3}$ & $\mathrm{~m}, \mathrm{~g}$ & $\mathrm{p}, \%$ \\
\hline 1 & 20,9 & 5,09 & 90,8 \\
\hline 2 & 20,8 & 4,80 & 91,3 \\
\hline 3 & 21,1 & 5,20 & 90,7 \\
\hline 4 & 20,0 & 4,41 & 91,7 \\
\hline
\end{tabular}



Rys. 3. Wynik badania mikroskopowego ciętych powierzchni piany aluminiowej: a) silnie zniekształcona powierzchnia cięta tarczą PFERD z wyraźnie pozamykanymi porami przez nieodcięte, a tylko zaginane fragmenty struktury; b) rozwinięta powierzchnia piany aluminiowej wysokiej jakości cięta przeznaczoną do stopów aluminium tarczą PRESI

Fig. 3. The result of microscopic examination of cut surface of the aluminum foam: a) highly deformed PFERD system cut surface with closed pores through uncut and bent pieces of structure; b) high quality aluminum foam with developed surface cut by PRESI system 
Z uwagi na konieczność odpowiedniego przygotowania powierzchni do klejenia, zalecaną przez producenta użytego kleju, klejoną powierzchnię zmatowiono papierem ściernym o wielkości ziarna P320.

Dokonano pomiaru chropowatości zgodnie z PNEN ISO 9013:2008. Do pomiaru użyto miernika chropowatości Hommel Etamic T8000 RC z głowicą TK300. Zastosowano następujące warunki pomiaru: $L_{t} 48 \mathrm{~mm}$, zakres $800 \mu \mathrm{m}$, filtr ISO11562(M1), posuw $0,5 \mathrm{~mm} / \mathrm{s}$.

$Z$ pomiarów chropowatości przedstawionych na rysunku 4 wynika, że obróbka powierzchni przed klejeniem poprawia chropowatość, która w przypadku obróbki papierem ściernym P320 wzrasta niemal dwukrotnie. Dodatkowym efektem jest ujednorodnienie powierzchni, które powinno wpłynąć na powtarzalność wyników pomiarów wytrzymałościowych.

Przeprowadzono procedurę klejenia złączy polegającą na odtłuszczeniu łączonych powierzchni acetonem, naniesieniu na powierzchnie blach wcześniej przygotowanej kompozycji kleju dwuskładnikowego, umieszczeniu grafitowych elementów dystansujących, montażu kolejnych elementów złącza oraz - po wstępnym docisku - usunięciu nadmiaru kleju. Czas uzyskania pełnej wytrzymałości kleju wynosi $12 \mathrm{~h}$. Próby wytrzymałościowe zostały przeprowadzone po upłynięciu $48 \mathrm{~h}$.

\section{Badanie złączy testowych}

Badania wytrzymałościowe wykonano na maszynie wytrzymałościowej Instron $5585 \mathrm{H}$ sterowanej za pomocą oprogramowania Bluehill 2. Parametry środowiskowe zostały mierzone termometrem - higrometrem Termometerfabriken Viking AB.

W czasie próby rozciągania doszło do wyrwania części piany aluminiowej, ale nie doszło do zniszczenia połączenia klejowego. Na naprężenie, które zniszczyło próbkę, składały się: siła rozciągająca oraz moment gnący, którego źródłem była wyciągana spomiędzy dwóch pian przyklejona blacha. Przebieg procesu rozciaggania próbki został udokumentowany w postaci serii zdjęć przedstawiających zmiany w geometrii próbki (rys. 5). Widoczne jest początkowe równomierne odkształcenie ze wzrastającą krzywizną zewnętrznej krawędzi piany po lewej stronie potęgujące moment gnący. Pęknięcie próbki z lewej strony nastąpiło wskutek rozerwania, które powstało przy stosunkowo małym odkształceniu. Piana z prawej strony próbki została wyrwana przez dolną blachę w końcowej fazie w wyniku zwiększającej się deformacji.

a)

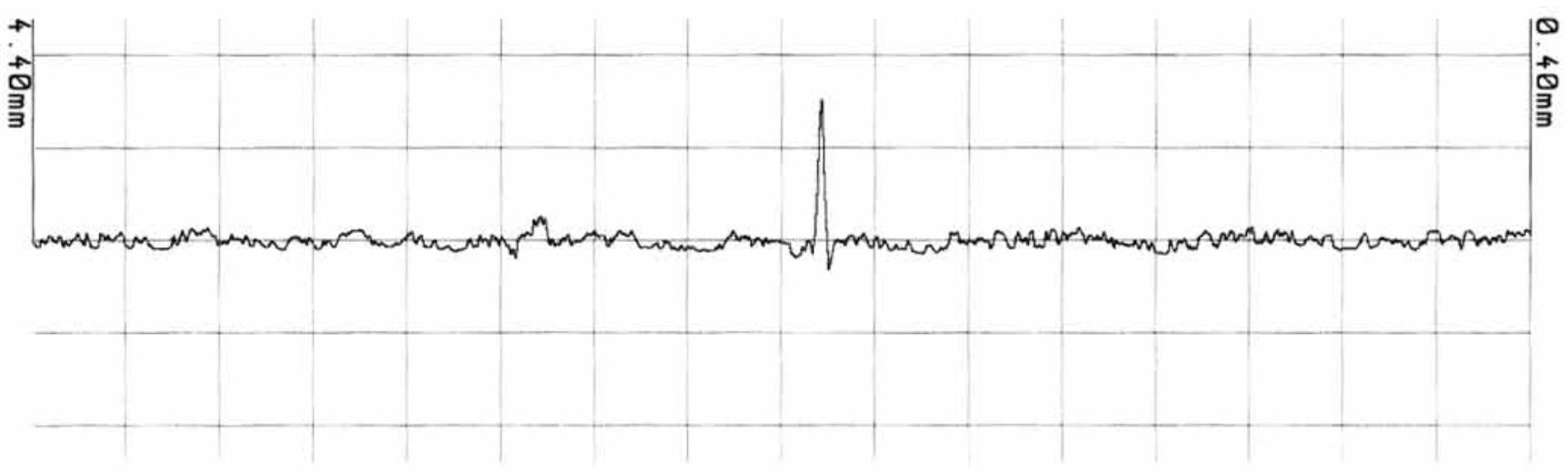

b)

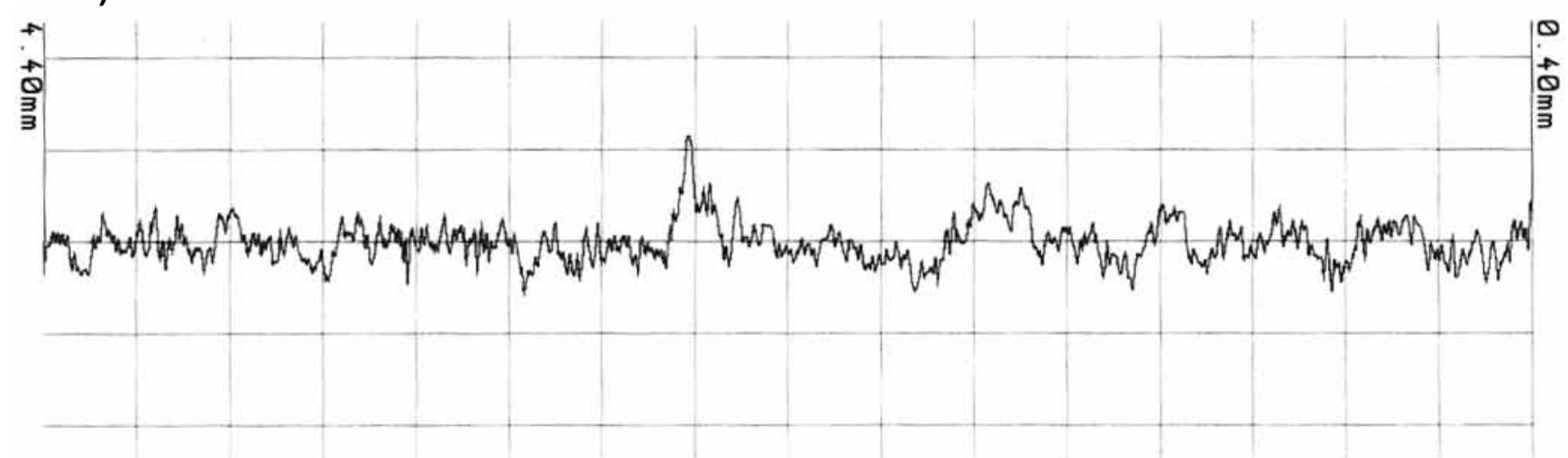

Rys. 4. Wyniki pomiarów chropowatości: a) próbka nieobrabiana: Ra: $0,308 \mu \mathrm{m}$; R3z: $1,18 \mu \mathrm{m}$; Rz $3,09 \mu \mathrm{m}$; b) próbka po obróbce: Ra: 0,850 $\mu \mathrm{m}$; R3z: 3,97 $\mu \mathrm{m}$; Rz 5,60 $\mu \mathrm{m}$

Fig. 4. The results of the roughness measurements: a) unsanded sample Ra: $0.308 \mu \mathrm{m}$; R3z: $1.18 \mu \mathrm{m}$; Rz $3.09 \mu \mathrm{m}$; b) grounded sample: Ra: $0.850 \mu \mathrm{m}$; R3z: $3.97 \mu \mathrm{m}$; Rz $5.60 \mu \mathrm{m}$ 



Rys. 5. Zwiększające się odkształcenie rozciąganej próbki wytrzymałościowej. Strzałką zaznaczono pęknięcie inicjujące zerwanie piany Fig. 5. Increasing tension deformation of the sample. Fracture initiating rupture was marked
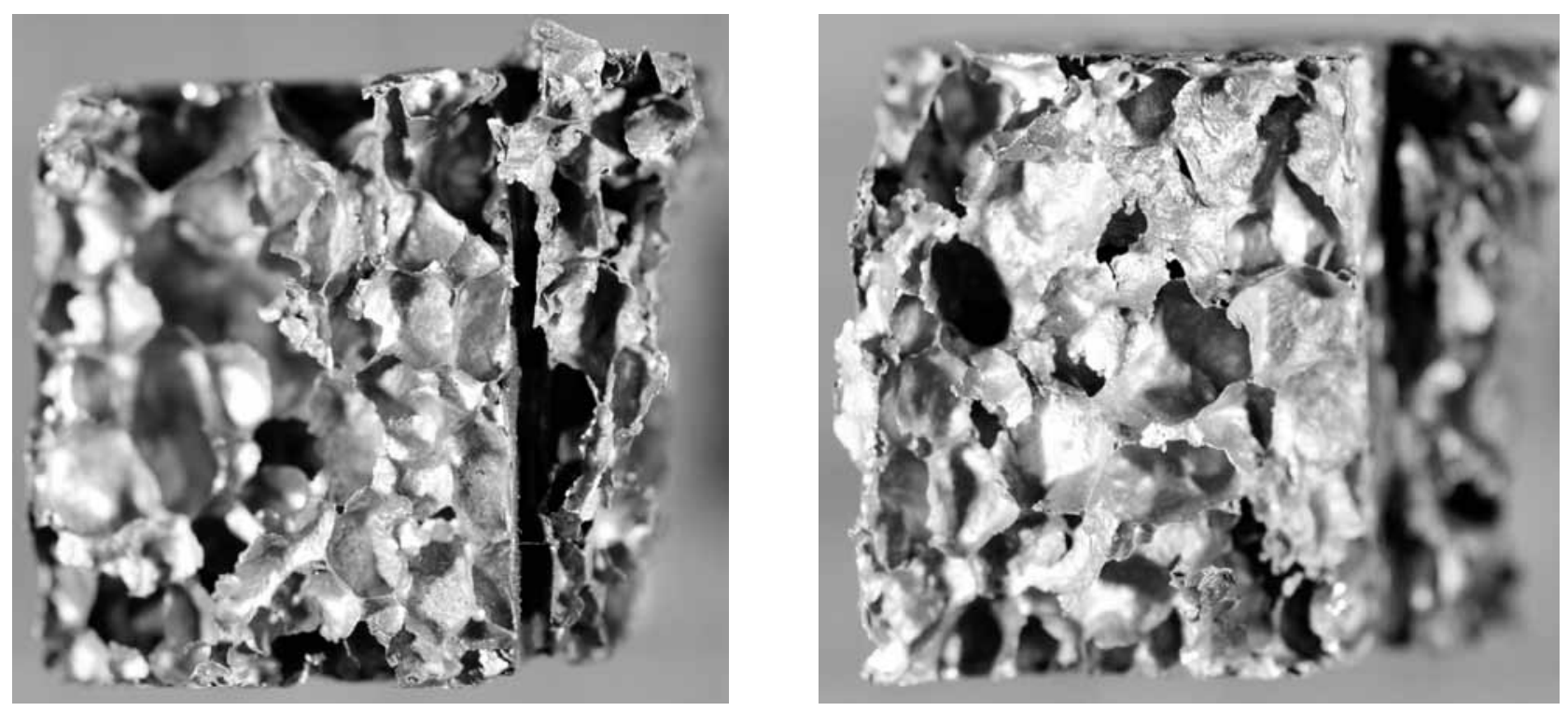

Rys. 6. Przełomy próbek. Widoczne odkształcenia plastyczne metalu. Przebieg pęknięcia prowadzi wzdłuż powierzchni o najmniejszej wytrzymałości

Fig. 6. Fractures of samples. Visible plastic deformation of foam metal. Course of crack leads along the surface of with the lowest strength 
Przykład ten ilustruje, jak zróżnicowaną strukturę mają piany aluminiowe. Podczas gdy obliczona porowatość oscyluje wokół $91 \%$ i nie zmienia się w znaczącym stopniu, to mikrostruktura podlega losowym parametrom, co powoduje że występują w niej liczne karby obniżające właściwości wytrzymałościowe i pogarszające powtarzalność wyników badań.

Spostrzeżenia potwierdzają obserwacje makroskopowe przełomów przedstawione na rysunku 6 .

Wpływ zastosowanych systemów cięcia widoczny jest na rysunku 7 , gdzie ukazano różnice $w$ wypełnieniu porów klejem oraz brak odstępu pomiędzy klejonymi materiałami. Strzałką zaznaczono niewielkie ilości kleju

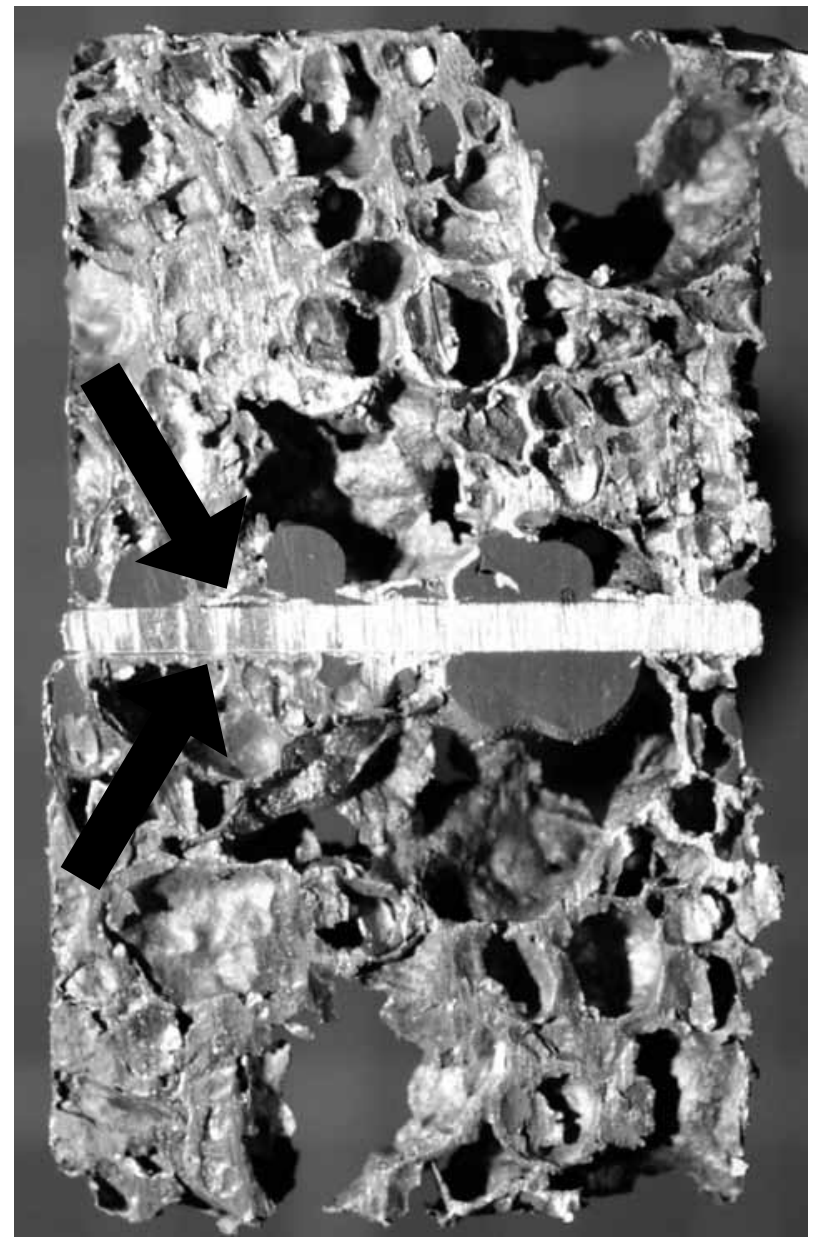

zamknięte w przestrzeniach pomiędzy elementami.

Przekroje poprzeczne wykazują duże różnice w budowie spoiny (rys. 7). Stopień wypełnienia porów klejem jest wyższy dla próbki, której powierzchnia cięta była dedykowaną do stopów aluminium tarczą. Na próbce ciętej systemem PFERD widać wyraźnie fragmenty metalu, które zamiast zostać odcięte uległy zawinięciu zasłaniając pory - blokując drogę dla ciekłego kleju penetrującego powierzchnię piany. Z uwagi na ograniczoną dostępną przestrzeń porów otwartych w próbce oraz brak odstępu pomiędzy elementami część kleju została zamknięta w wąskich przestrzeniach.

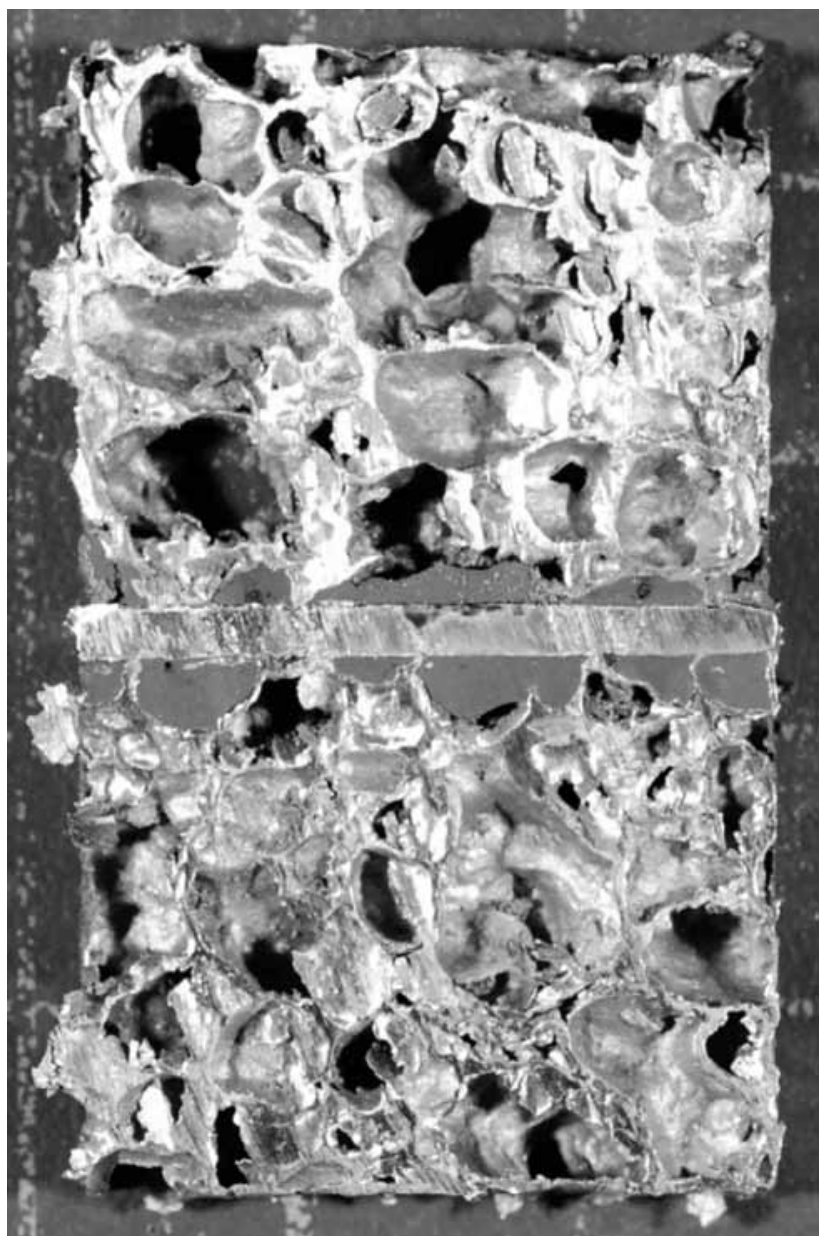

Rys. 7. Przekrój poprzeczny spoin na próbkach wytrzymałościowych: a) ciętych systemem PFERD, b) ciętych tarczą PRESI

Fig. 7. Cross section of the joints on samples: a) cutted PFERD system, b) cutted by PRESI

\section{Wnioski}

W wyniku przeprowadzonych badań ustalono warunki przygotowania złączy klejowych pozwalających, aby w warunkach dalszych badań uzyskać miarodajne i łatwe do porównania wyniki. Dodatkowo ustalono procedury badań umożliwiające na ocenę wytwarzanych złączy.

W wykonanych złączach nie udało się uzyskać wymaganego odstępu pomiędzy łączonymi elementami. Zgodnie z zaleceniami odległość powinna wynosić $0,2 \div 0,5 \mathrm{~mm}$. Zastosowane grafitowe dystanse o grubości $0,5 \mathrm{~mm}$ miały zbyt małą wytrzymałość. Docisk podczas klejenia oraz wysokie punktowe naciski ścianek piany spowodowały ich zniszczenie.

Wytrzymałość uzyskanych złączy była wysoka. W czasie badań zniszczeniu uległy elementy $z$ piany aluminiowej. Ilość kleju, która wnika w pory, była wystarczająca do zapewnienia wymaganej wytrzymałości złącza. Uzasadnia to zastosowanie specjalistycznych narzędzi do cięcia aluminium, które wpływają korzystnie na zjawisko infiltracji 
warstwy wierzchniej piany ciekłym klejem. Wysoka porowatość pian oraz wystarczająca lepkość ciekłego kleju ułatwiły odprowadzenie powietrza ze spoiny. Nie odnotowano obecności pęcherzy powietrznych w złączu klejowym i samej klejowej spoinie.

Zastosowana w badaniach wstępnych procedura klejenia jest właściwa. Aby polepszyć siły wiązania pomiędzy klejem, a blachą, można zastosować do obróbki powierzchni papier ścierny o większym ziarnie, np. P80 zamiast P320. Możliwe jest również rozważenie zwiększenia ilości nakładanego kleju, który nie do końca wypełnił całą porowatość otwartą badanych próbek.

Określona w czasie przygotowania próbek średnia wartość porowatości wyniosła 91,1\% przy odchyleniu standardowym wynoszącym 0,465 , co wskazuje na przydatność metody wagowej.

Podczas badań wytrzymałościowych zniszczeniu uległy w obu przypadkach elementy kompozytowe piany. Obliczenia wytrzymałości zastosowanych materiałów poprzedzające badania wskazywały, że zniszczeniu ulegnie najsłabszy element złącza - klejowa spoina. Nie udało się potwierdzić obliczeń, gdyż zarejestrowana maksymalna siła zrywająca osiągnęła 15 razy mniejszą wartość od obliczeniowej przedstawionej w tablicy I.
Analizując odkształcenia w czasie próby rozciągania ustalono, że należy usztywnić elementy złącza przez: zastosowanie grubszych blach mocujących oraz wzmocnienia zewnętrznych powierzchni pian za pomocą przyklejonych blach aluminiowych. Rozwiązanie to pozwoli wyeliminować ugięcie do środka zewnętrznych powierzchni pian i ograniczyć niekorzystny moment zginający. Dodatkowo wzmocnienie piany pozwoli na ograniczenie jej grubości do wielkości większej od głębokości wnikania kleju z obydwu stron.

Modyfikacji powinna ulec także prędkość odkształcenia. Przy aktualnej wynoszącej $1 \mathrm{~mm} / \mathrm{min}$ proces rozciągania kończy się po $180 \div 240$ s., które odpowiadają odkształceniu $3 \div 4 \mathrm{~mm}$. Po upłynięciu tego czasu następuje powolna destrukcja próbki przy niskiej - stałej wartości rejestrowanej siły. Aby spełnić warunek podany w dokumentach normatywnych: $40 \div 90$ s czasu trwania zasadniczej części pojedynczej próby, należy zwiększyć prędkość odkształcenia do $3 \div 6 \mathrm{~mm} / \mathrm{min}$.

Opisane w pracy procedury badawcze dotyczą najbardziej istotnych aspektów badań połączeń klejowych aluminiowych pian z blachami. Aparatura pomiarowa użyta do badań została dobrana w sposób prawidłowy, co pozwoliło uzyskać jednoznaczne i dokładne wyniki w założonym wcześniej zakresie.

\section{Literatura}

[1] Grabian J.: Metalowe piany kompozytowe w przemyśle okrętowym, Szczecin 2012.

[2] Ashby M.F., Evans A.G., Fleck N.A., Gibson L.J., Hutchinson J.W., Wadley H.N.G.: Metal Foams: A Design Guide, Butterworth-Heinemann 2000.

[3] Sedliaková N., Simančík F., Kováčik J., Minár P.: Joining of Aluminium Foams, Metallschäume: Proc. of Symposium Metallschäume, Bremen 3/1997.

[4] Bartolucci S.: Commercial application of aluminium honeycomb and foam in load bearing tubular structures, Massachusetts Institute of Technology, 9/2004.

[5] Degischer H. P., Kriszt B.: Handbook of cellular metals: production, processing, applications, $\mathrm{CCH}$ Verglag $\mathrm{GmbH}, 2002$.

[6] Olurin O. B., Fleck N. A., AshbyM. F.: Joining of aluminium foams with fasteners and adhesives, Journal of Materials and Science 35/2000.

[7] Burzer J., Bernard T., Bergmann H. W.: Joining of aluminium structures with aluminium foams, 1998 MRS Spring Meeting.
[8] Bernard T., Burzer J., Bergmann H. W.: Mechanical properties of semifinished joined to aluminium foams, Journal of Materials Procesing Technology 115/2001.

[9] Krajewski S. , Nowacki J.: Preparation of Aluminium Foam Edges For Welding, Advances in Materials Science, vol. 13, no. 3 (37), Sep-tember 2013.

[10] Nowacki J., Grabian J., Krajewski S.: Problemy lutowania pian aluminiowych, Przegląd Spawalnictwa, 1(2014).

[11] Panowicz R., Kołodziejczyk D., Sybilski K., Barnat W., Niezgoda T.: Analiza numeryczna dynamicznego oddziaływania fali ciśnienia na złożoną strukturę panelu energochłonnego, Przegląd Mechaniczny nr 11/2012.

[12] Klasztorny M., Małachowski J., Dziewulski P., Nycz D., Gotowicki P.: Badania eksperymentalne i modelowanie piany aluminiowej AL-PORAS, Modelowanie inżynierskie 42/2012.

\section{Podziękowania}

Artykuł przygotowany w ramach projektu NCBiR Nr PBS1/A5/6/2012 pt. Kompozytowe piany metalowe - obróbka cieplna, cięcie, łączenie 